\title{
Peningkatan Efisiensi Distilasi Air Energi Surya Menggunakan Pengapung
}

\author{
FA. Rusdi Sambada ${ }^{1)^{*}}$ dan Fidelis Ananta1) \\ 1) Program Studi Teknik Mesin, Universitas Sanata Dharma \\ Kampus III Paingan Maguwoharjo, Depok, Sleman, Yogyakarta, Indonesia \\ Naskah diterima 02/10/2020; direvisi 05/11/2020; disetujui 14/11/2020 \\ doi: https://doi.org/10.24843/JEM.2020.v13.i02.p05
}

\begin{abstract}
Abstrak
Ketersediaan air minum bagi sebagian masyarakat di Indonesia masih menjadi masalah terutama di daerah terpencil. Banyak sumber air terkontaminasi garam dan zat-zat lain yang berbahaya bagi kesehatan. Cara yang paling sederhana untuk menjernihkan air terkontaminasi adalah dengan distilasi air energi surya. Hal tersebut didukung potensi energi surya di Indonesia yang cukup besar. Distilasi air energi surya jenis bak merupakan alat distilasi yang paling sederhana namun efisiensinya masih rendah. Salah satu faktor rendahnya efisiensi adalah proses penguapan yang tidak efisien, karena besarnya massa air yang terpanasi pada satu saat. Memperkecil massa air yang terpanasi pada satu saat dapat dilakukan dengan menggunakan pengapung. Penggunaan pengapung untuk meningkatkan efisiensi penguapan sangat dipengaruhi oleh bahan absorber, massa air dalam bak dan massa air yang terpanasi pada satu saat. Tujuan penelitian ini adalah menganalisis efek bahan absorber, massa air dalam bak dan massa air yang terpanasi pada satu saat terhadap efisiensi distilasi yang dihasilkan. Penelitian dilakukan secara eksperimen dalam laboratorium dengan membuat dua buah model distilasi air energi surya jenis bak. Model pertama adalah distilasi air energi surya dengan pengapung dan model kedua tanpa pengapung sebagai pembanding. Variabel yang divariasikan pada penelitan ini adalah (1) bahan absorber yakni kain, tisu dan alumunium foil, (2) variasi jumlah massa air dalam bak sebesar $0,6 \mathrm{~kg}$ dan $1,5 \mathrm{~kg}$ dan (3) variasi massa air yang dipanasi pada suatu saat sebesar $0,36 \mathrm{~kg}, 0,93 \mathrm{~kg}, 1,22 \mathrm{~kg}$ dan $1,5 \mathrm{~kg}$. Pada penelitian ini variabel yang di ukur adalah temperatur kaca penutup $\left(T_{K}\right)$, temperatur absorber $\left(T_{A}\right)$ dan volume air yang dihasilkan $(\mathrm{m})$. Hasil penelitian menunjukkan peningkatan efisiensi terbaik terhadap distilasi tanpa pengapung sebesar $63,2 \%$ diperoleh dengan bahan absorber tisu, volume air dalam bak 1,5 liter dan massa air yang terpanasi pada satu saat sebesar $0,36 \mathrm{~kg}$. Air distilasi yang dihasilkan adalah $0,59 \mathrm{liter} /\left(\mathrm{jam} . \mathrm{m}^{2}\right.$ ) dengan efisiensi $52.7 \%$.
\end{abstract}

Kata kunci: distilasi, pengapung, jumlah massa air, efisiensi.

\section{Abstract}

The availability of drinking water for some people in Indonesia is still a problem, especially in remote areas. Many water sources are contaminated with salt and other substances that are harmful to health. The simplest way to purify contaminated water is by solar water distillation. This is supported by the large potential of solar energy in Indonesia. Basin type solar water distillation is the simplest distillation type, but the efficiency is still low. One of the low-efficiency factors is the inefficient evaporation process, due to the large mass of heated water at one time. Reducing the mass of heated water at one time can be done by using floats. The use of floats to increase evaporation efficiency is strongly influenced by the absorber material, the mass of water in the basin, and the heated mass of water at one time. This study aimed to analyze the effect of the absorber material, the mass of water in the basin, and the mass of water heated at one time on the resulting distillation efficiency. The research was carried out experimentally in the laboratory by making two models of basin-type solar water distillation. The first model is the distillation of solar energy water with floats and the second model without floats. The variables that were varied in this research were (1) the absorber material, namely cloth, tissue, and aluminum foil, (2) variations in the amount of water mass in the basin of $0.6 \mathrm{~kg}$ and $1.5 \mathrm{~kg}$, and (3) variations in the mass of water heated at one time of $0.36 \mathrm{~kg}, 0.93 \mathrm{~kg}, 1.22 \mathrm{~kg}$ and $1.5 \mathrm{~kg}$. In this study, the measured variables were covered glass temperature $\left(T_{K}\right)$, absorber temperature $\left(T_{A}\right)$, and volume of water produced $(\mathrm{m})$. The results showed that the best efficiency increase for distillation without floating was $63.2 \%$ obtained with tissue absorber material, the volume of water in the 1.5-liter basin, and the mass of water heated at one time was $0.36 \mathrm{~kg}$. The resulting distilled water is 0.59 liter / (hour. $\mathrm{m}^{2}$ ), with an efficiency of $52.7 \%$.

Keywords: distillation, float, amount of water mass, efficiency.

\section{Pendahuluan}

Air minum merupakan salah satu kebutuhan pokok manusia. Tidak semua daerah di Indonesia mempunyai sumber air dengan kualitas yang memenuhi syarat sebagai air minum. Selain tidak mempunyai sumber air yang baik, beberapa daerah di Indonesia tidak memiliki akses yang mudah untuk mendapatkan air minum, misalnya di daerah terpencil. Sering kali sumber air yang ada tercemar oleh zat-zat yang berbahaya bagi kesehatan jika dikonsumsi secara langsung, misalnya garam, logam berat, bakteri, tanah dan lainnya. Ada beberapa cara untuk menjernihkan air yang terkontaminasi sehingga menjadi air yang layak diminum. Salah satu cara yang mudah dan mudah adalah distilasi air energi surya. Sebagai negara tropis. Indonesia mempunyai potensi energi surya tiap tahun yang cukup besar. Distilasi air energi surya jenis bak (Gambar 1) merupakan jenis yang paling sederhana diantara jenis distilasi air energi surya yang ada.

Permasalahan umum pada distilasi air energi surya adalah masih rendahnya efisiensi. Salah satu sebab rendahnya efisiensi adalah proses penguapan air yang tidak efisien. Pada distilasi air energi surya jenis bak, tidak efisiennya proses penguapan disebabkan oleh jumlah massa air yang dipanaskan terlalu banyak. Jenis 
bahan absorber juga berpengaruh pada proses penguapan. Penelitiaan ini bertujuan menganalisis efek pengapung untuk meningkatkan efisiensi proses penguapan.

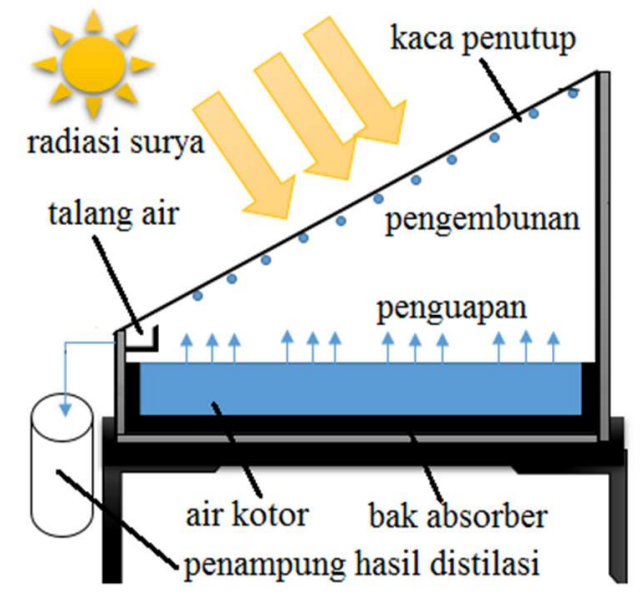

Gambar 1. Distilasi air energi surya jenis bak

Pengapung yang dimaksud adalah beberapa silinder dari bahan aluminium tipis yang diletakkan dalam bak distilasi. Tiap silinder diberi kaki dari kawat. Setiap silinder diberi bahan yang mempunyai sifat kapilaritas air sebagai absorber. Air dalam bak akan mengalir ke dinding silinder karena sifat kapilaritas absorber. Metode ini akan meningkatkan efisiensi penguapan sehingga efisiensi distilasi juga meningkat.

Penelitian distilasi air energi surya umumnya bertujuan meningkatkan efisiensi. Upaya meningkatkan efisiensi dengan menambahkan 100 silinder katun berisi pasir. pada distilasi jenis bak meningkatkan kapasitas panas dan luas permukaan pada distilasi jenis bak. Hasil air distilasi meningkat $28,56 \%$ dan $30,99 \%$ dibandingkan distilasi konvensional pada massa air dalam bak $30 \mathrm{~kg}$ dan $40 \mathrm{~kg}$, [1], Studi penyimpan energi panas berupa balok yang diselimuti kain goni pada distilasi jenis bak dapat meningkatkan hasil dari $5 \mathrm{~kg} /\left(\mathrm{m}^{2}\right.$.hari) menjadi $5,9 \mathrm{~kg} /\left(\mathrm{m}^{2}\right.$.hari) pada massa air dalam bak sebesar $20 \mathrm{~kg}$ [2]. Penambahan pin/paku bersirip untuk meningkatkan penguapan menghasilkan peningkatan produktivitas distilasi sekitar $55 \%$ [3]. Penelitian penggunaan sirip persegi panjang berbahan aluminium dan ditutupi dengan kain yang berbeda menunjukkan bahwa hasil air distilasi tebanyak yaitu $3,58 \mathrm{~kg} / \mathrm{hari}$ diperoleh dengan kain katun hitam muda.[4]. Modifikasi bentuk absorber dengan groove, fin, baffles dan partisi dapat meningkatkan temperatur air [5]. Hasil penelitian Nagarajan [6] menunjukkan penggunaan baffles dapat meningkatkan produksi 1.68 kali dibanding tanpa baffles. Sharon [7] meneliti penggunaan partisi basin dan produksi naik $19.76 \%$. Penggunaan beberapa material kain absorber diteliti oleh Hansen [8]. Sifat-sifat kain mempengaruhi temperatur air di absorber. Hasil terbaik sebesar 4.28 I/hari diperoleh dengan bahan absorber water coral fleece with weir mesh-stepped absorber plate. Kabel [9] dan Samuel [10] memanfaatkan air buangan yang keluar dari distilasi jenis kain sebagai air masuk pada distilasi jenis bak. Peningkatan produksi yang diperoleh sebesar $46.23 \%$ [9] dan 25.75\% [10]. Penelitian ini menggunakan metode yang berbeda dari penelitian sebelumnya dalam meningkatkan efisiensi distilasi air energi surya. Pada penelitian ini efisiensi distilasi air energi surya jenis bak ditingkatkan dengan meningkatkan efisiensi proses penguapan. Peningkatan proses penguapan dapat dilakukan dengan menggunakan pengapung yang diberi bahan absorber yang memiliki sifat kapilaritas air yang baik. Dengan menggunakan pengapung dan bahan absorber, massa air yang terpanasi pada satu saat dapat diminimalkan. Dengan minimalnya massa air yang terpanasi pada satu saat, proses penguapan menjadi lebih efisien dan efisiensi distilasi dapat ditingkatkan

\section{Metode Penelitian}

Penelitian dilakukan secara eksperimen di dalam laboratorium Perpindahan Panas Universitas Sanata Dharma Yogyakarta. Dua model distilasi air energi surya jenis bak terdiri dari model distilasi air energi surya jenis bak dengan pengapung (DDP) dan distilasi konvensional. Distilasi konvensional adalah distilasi air tanpa pengapung (DTP). Distilasi DDP adalah distilasi yang diteliti dan distilasi DTP digunakan sebagai pembanding.

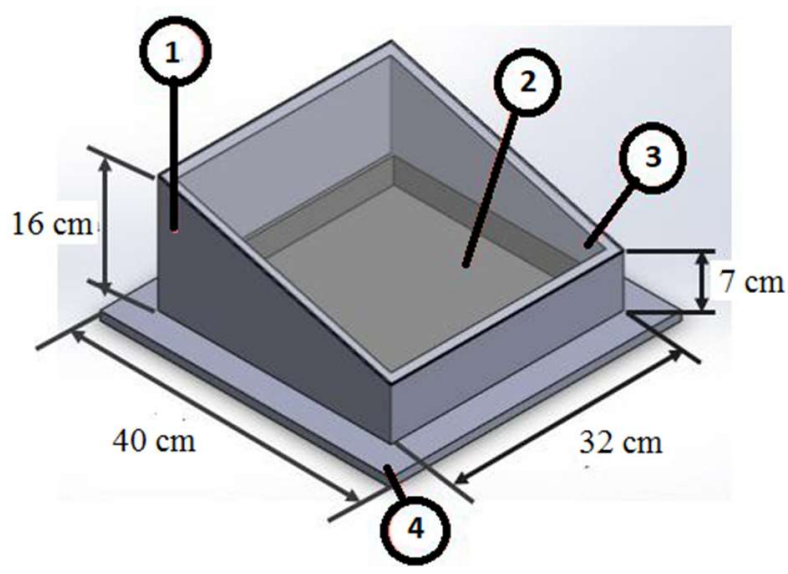

Gambar 2. Skema distilasi DDP dan DTP

Distilasi DDP dan DTP pada penelitian ini (Gambar 2) terbuat dari multipleks dengan tebal $12 \mathrm{~mm}$ dan ukuran alas $32 \mathrm{~cm} \times 32 \mathrm{~cm}$. Bak distilasi yang juga berfungsi sebagai absorber terbuat dari alumunium dengan ukuran $30 \mathrm{~cm}$ x $30 \mathrm{~cm}$. Tebal kaca penutup adalah $3 \mathrm{~mm}$ dan kemiringan kaca penutup distilasi $15^{\circ}$. Pengapung berbentuk silinder terbuat dari plat aluminium tipis (Gambar 3). Silinder mempunyai kaki dari kawat dan diletakkan dalam bak yang berisi air yang akan didistilasi (Gambar 4). Kaki pada silinder dibuat agar silinder tidak bersentuhan dengan air dalam bak distilasi sehingga energi panas yang diterima absorber tidak berpindah ke dalam air di bak. Silinder diselubung bahan yang mempunyai sifat kapilaritas air misalnya kain yang berfungsi sebagai absorber. Ujung kain terendam air dalam bak sehingga air akan mengalir ke atas yakni ke dinding silinder karena sifat kapilaritas kain. Ukuran silinder yang digunakan memiliki diameter $5,5 \mathrm{~cm}$ dan panjang $10,5 \mathrm{~cm}$. 


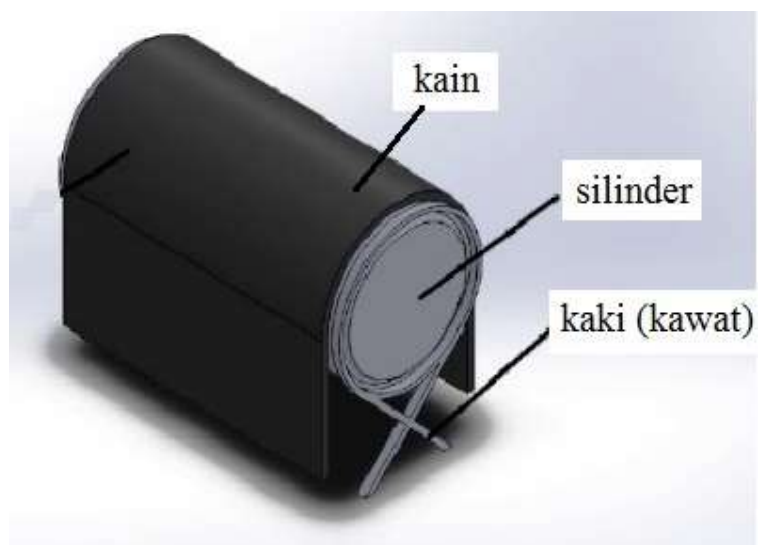

Gambar 3. Bagian-bagian pengapung

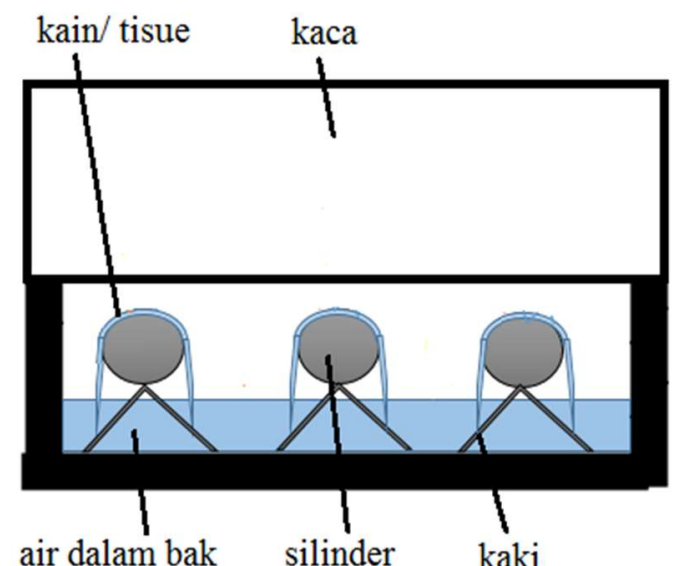

Gambar 4. Pengapung di dalam model distilasi air energi surya jenis bak (tampak depan)

Pada pengambilan data, tiap distilasi DDP dan DTP mendapat radiasi panas dari lampu sebanyak 3 buah dengan radiasi panas setara $375 \mathrm{~W} / \mathrm{m}^{2}$. Skema alat (Gambar 5) terdiri dari: (1) rangka model distilasi, (2) kipas angin, (3) rangka kipas angin dan lampu, (4) lampu pemanas, (5) model distilasi, (6) alas model distilasi dan (7) penampung air hasil distilasi.

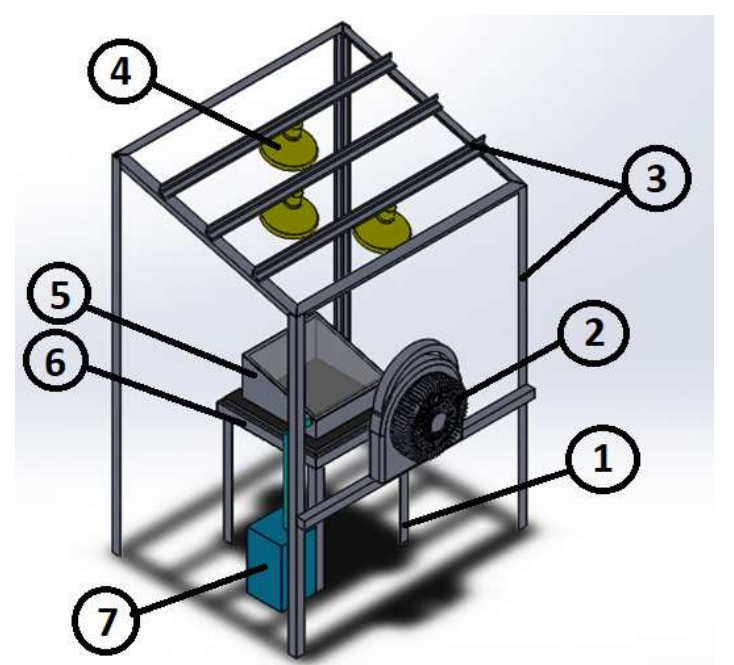

Gambar 5. Skema alat distilasi air energi surya jenis bak dengan lampu pemanas

Pada penelitian ini dilakukan 3 jenis variasi untuk mengungkap efek pengapung terhadap efisiensi dan banyak air distilasi yang dihasilkan. Pertama adalah variasi dengan jenis absorber yakni kain, tisu dan kain dengan alumunium foil. Kedua adalah variasi jumlah massa atau volume air dalam bak distiasi yaitu 0,6 dan 1,5 liter. Ketiga adalah variasi massa air yang terpanasi dalam satu saat. Massa air yang terpanasi dalam satu saat adalah jumlah massa air pada absorber dan massa air yang berada di sela-sela atau celah antar silinder. Pada distilasi DTP jumlah massa air yang terpanasi pada satu saat adalah jumlah massa air dalam bak, karena pada distilasi DTP tidak menggunakan silinder pengapung.

Pada distilasi DDP, penggunaan silinder pada bak, menyebabkan adanya celah air yang berada antara silinder satu dengan yang lainnya (Gambar 6). Pada penggunaan silinder sebanyak 12 , hampir seluruhnya menutupi bak absorber, namun tetap memiliki sedikit celah. Massa air yang terpanasi dalam satu saat pada celah merupakan hasil perkalian antara luasan celah dengan kedalaman air. Semakin banyak silinder yang digunakan, semakin kecil luasan celah, sehingga massa air pada celah yang terpanasi semakin sedikit. Dengan kata lain sebagian besar massa air yang terpanasi adalah massa air pada absorber (misalnya kain). Massa air di kain pada satu saat sangat sedikit karena tebal kain hanya sekitar $2 \mathrm{~mm}$. Dengan kata lain semakin banyak silinder yang digunakan semakin sedikit massa air yang terpanasi pada satu saat. Hubungan massa air yang terpanasi dalam satu saat dengan jumlah silinder dapat dilihat pada Tabel 1

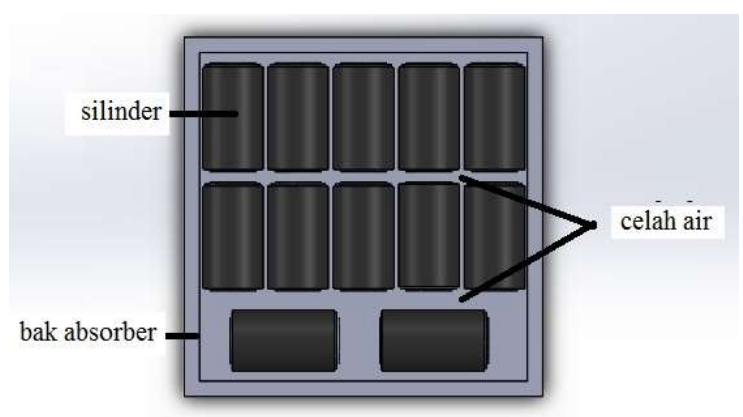

Gambar 6. Ilustrasi celah air pada variasi penggunaan 12 silinder

Tabel 1. Hubungan massa air yang terpanasi dalam suatu saat dengan jumlah silinder

\begin{tabular}{|c|c|}
\hline Jumlah Silinder & Massa Air yang Terpanasi $(\mathrm{kg})$ \\
\hline 3 silinder & 1.22 \\
\hline 6 silinder & 0.93 \\
\hline 12 silinder & 0.36 \\
\hline
\end{tabular}

Ekksperimen dilakukan selama 2 jam untuk tiap variasi. Variabel yang diukur adalah temperatur absorber, Ta $\left({ }^{\circ} \mathrm{C}\right)$, temperatur kaca penutup, Tk $\left({ }^{\circ} \mathrm{C}\right)$ dan volume air distilasi yang dihasilkan, $m$ (liter). Pada eksperimen, semua data temperatur air dan hasil air distilasi di ukur dengan sensor dan direkam dengan mikrokontroler Arduino. Tiap 10 detik. Efisiensi yang dihasilkan distilasi DDP dan DTP diperoleh dengan persamaan:

$$
\eta=\frac{m_{g} \cdot h_{f g}}{A_{C} \cdot \int_{0}^{t} G \cdot d t}
$$


dengan $\mathrm{m}_{\mathrm{g}}$ adalah hasil air distilasi $(\mathrm{kg})$, hfg adalah panas laten penguapan $(\mathrm{J} / \mathrm{kg}), A_{c}$ adalah luasan alat distilasi $\left(\mathrm{m}^{2}\right), \mathrm{G}$ adalah radiasi panas yang datang pada model distilasi $\left(\mathrm{W} / \mathrm{m}^{2}\right)$, dan $\mathrm{dt}$ adalah lama waktu pemanasan (detik).

\section{Hasil dan Pembahasan}

Hasil dan pembahasan disampaikan dalam tiga bagian. Bagian pertama akan membahas efek jenis absorber terhadap hasil dan efisiensi distilasi DDP dan DTP. Bagian kedua akan membahas efek jumlah massa air dalam bak terhadap hasil dan efisiensi distilasi DDP dan DTP. Bagian ketiga akan membahas efek massa air yang terpanasi pada satu saat terhadap hasil dan efisiensi distilasi DDP dan DTP.

\subsection{Efek variasi jenis absorber}

Pada eksperimen untuk mengetahui efek variasi jenis absorber pada hasil dan efisiensi distilasi digunakan jenis absorber alumunium foil, kain dan tisu. Jumlah silinder pengapung yang digunakan pada distilasi DDP sebanyak 12 silinder.

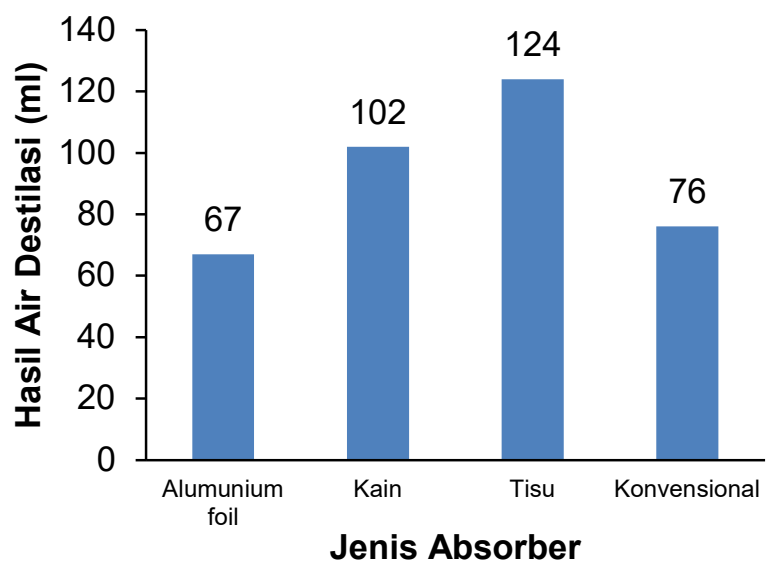

Gambar 7. Hasil air distilasi pada variasi jenis absorber

Gambar 7 menunjukkan absorber tisu menghasilkan air distilasi terbanyak. Absorber tisu merupakan absorber yang paling tipis sehingga massa air yang terkandung pada absorber tisu adalah yang paling sedikit. Massa air yang sedikit menyebabkan proses penguapan air berlangsung lebih cepat. Dari grafik terlihat hasil distilasi DDP $63,2 \%$ lebih banyak dari DTP

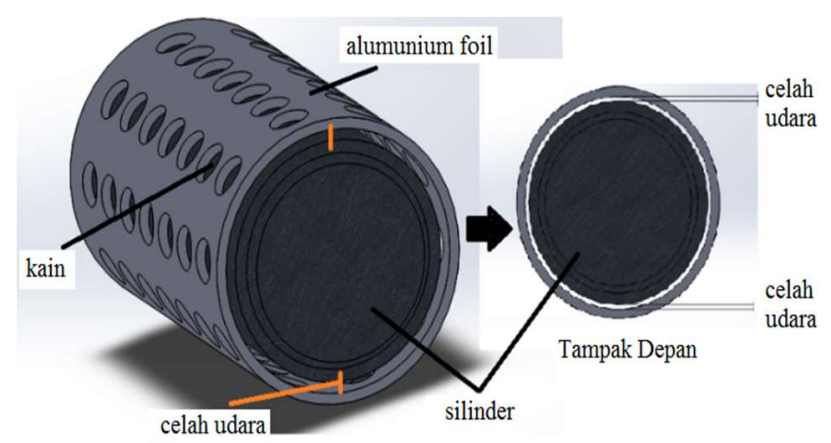

Gambar 8. bagian-bagian absorber alumunium foil

Absorber alumunium foil yang dimaksud pada penelitian ini adalah absorber kain yang diselubungi alumunium foil berlubang (Gambar 8). Tujuan memberi selubung alumunium foil pada kain adalah agar proses pemanasan air pada kain lebih baik. Namun dari hasil yang diperoleh, absorber alumunium foil adalah yang terendah. Hasil terendah pada absorber alumunium foil disebabkan kontak antara kain dan alumunium foil yang buruk yakni terdapat celah udara antara kain dan alumunium foil. Celah udara menyebabkan pemanasan kain terhambat, bahkan alumunium foil menjadi penghalang radiasi panas yang seharusnya diterima kain.

Hasil air distilasi berbanding lurus dengan efisiensi (Persamaan 1). Hasil air distilasi absorber tisu adalah yang terbanyak, sehingga efisiensi distilasi dengan absorber tisue juga yang terbesar (Gambar 9) yakni $52,7 \%$

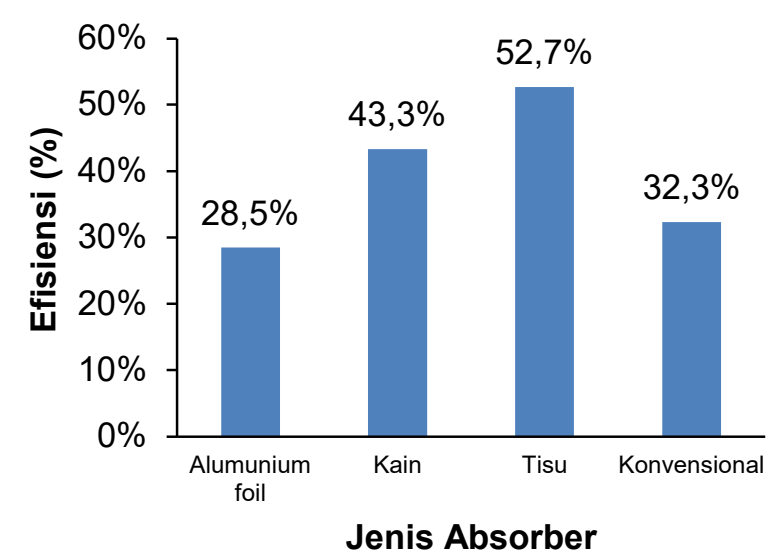

Gambar 9. Efisiensi distilasi pada variasi jenis absorber

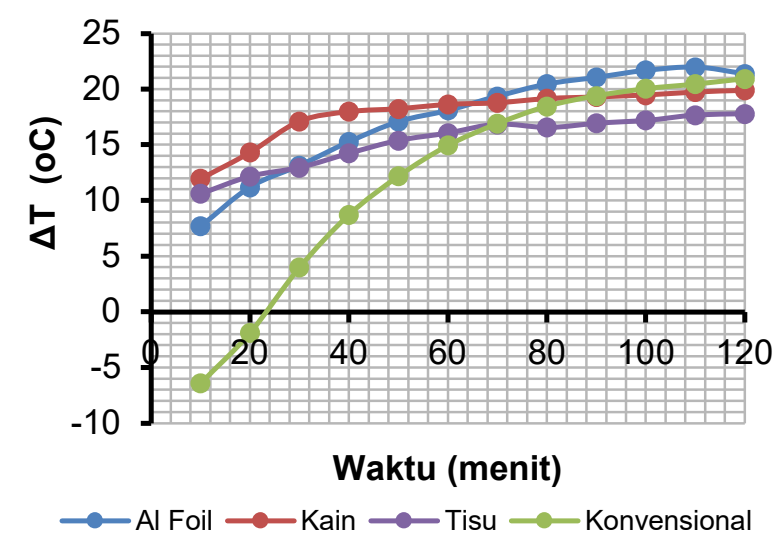

Gambar 10. Perubahan $\Delta T$ pada variasi jenis absorber

Perpindahan panas dan massa uap dari absorber ke kaca penutup terjadi secara konveksi. Perpindahan panas dan massa uap secara konveksi ditentukan oleh beda temperatur antara air di absorber dengan temperatur kaca $(\Delta \mathrm{T})$. Semakin besar $\Delta \mathrm{T}$, semakin cepat uap berpindah dari absorber ke kaca. Gambar 10 menunjukkan $\Delta T$ tiap 10 menit selama 2 jam pengambilan data. Terlihat bahwa $\Delta T$ distilasi jenis konvensional (DTP) pada saat awal memiliki nilai negatif. Ini dikarenakan temperatur kaca lebih tinggi dibandingkan temperatur absorber pada saat awal. Pada nilai $\Delta T$ negatif uap tidak bergerak ke kaca walaupun uap sudah terbentuk pada permukaan air di absorber. 


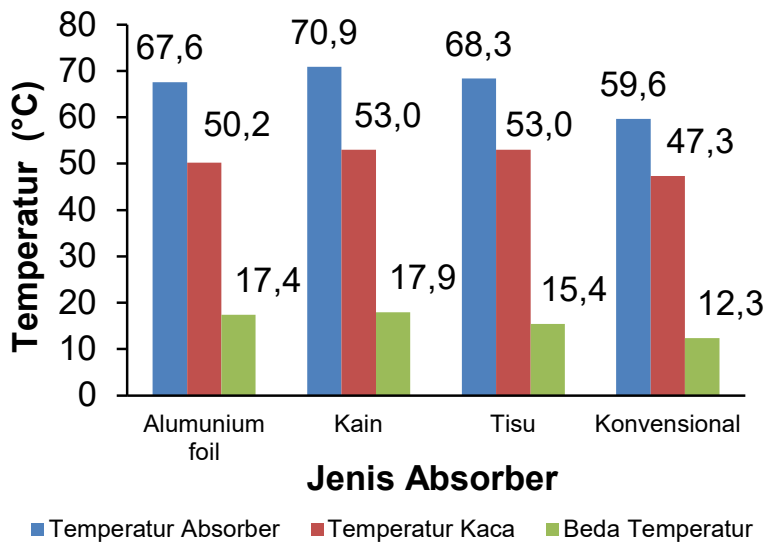

Gambar 11. Rata-Rata Temperatur Absorber, Kaca, dan $\Delta \mathrm{T}$ pada variasi jenis absorber

Gambar 11 menunjukkan rata-rata temperatur kaca, temperatur absorber dan $\Delta T$ selama 2 jam pengambilan data. Temperatur absorber rata-rata tertinggi adalah kain, karena absorbtivitas kain yang tinggi. Namun hasil dan efisiensi terbaik adalah absorber tisu, karena massa air yang terpanasi pada satu saat pada absorber tisu lebih sedikit dibandingkan pada absorber kain.

\subsection{Efek Jumlah Massa Air dalam Bak}

Hasil dan efisiensi terbaik pada variasi jenis bahan absorber adalah absorber tisu. Pada variasi jumlah massa air dalam bak, jenis bahan absorber yang digunakan adalah tisu dengan jumlah pengapung sebanyak 12 silinder. Jumlah massa air dalam bak divariasikan sebesar $0,6 \mathrm{~kg}$ dan $1,5 \mathrm{~kg}$ atau sebanyak 0,6 liter dan 1,5 liter.

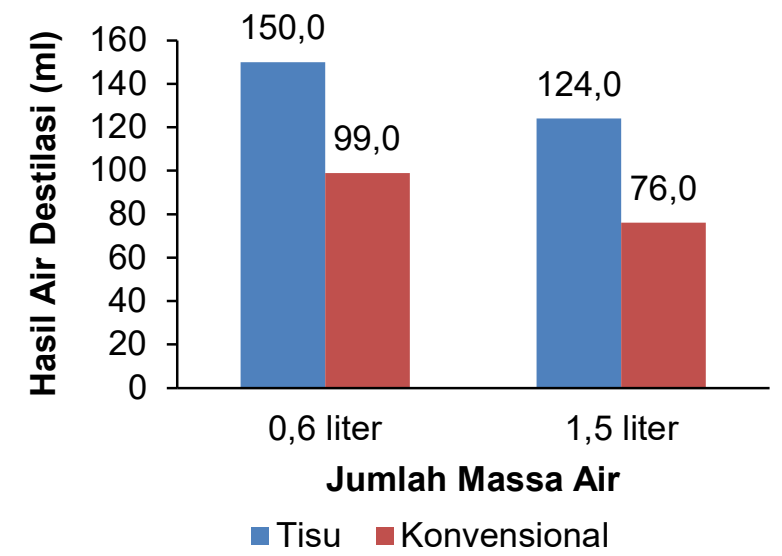

Gambar 12. Hasil Distilasi pada variasi jumlah air dalam bak 0,6 dan 1,5 liter

Gambar 12 menunjukan hasil air distilasi DDP dengan absorber tisu dan distilasi DTP (konvensional) pada jumlah massa air dalam bak sebanyak 0,6 liter dan 1,5 liter. Hasil air distilasi terbanyak pada DDP dan DTP diperoleh pada jumlah massa air dalam bak sebanyak 0,6 liter. Pada massa air 0,6 liter hasil air distilasi DDP 51,3\% lebih banyak dari DTP. Pada massa air 1,5 liter hasil air distilasi DDP 63,2\% lebih banyak dari DTP. Dengan kata lain penggunaan pengapung lebih efektif pada massa air dalam bak yang lebih banyak.

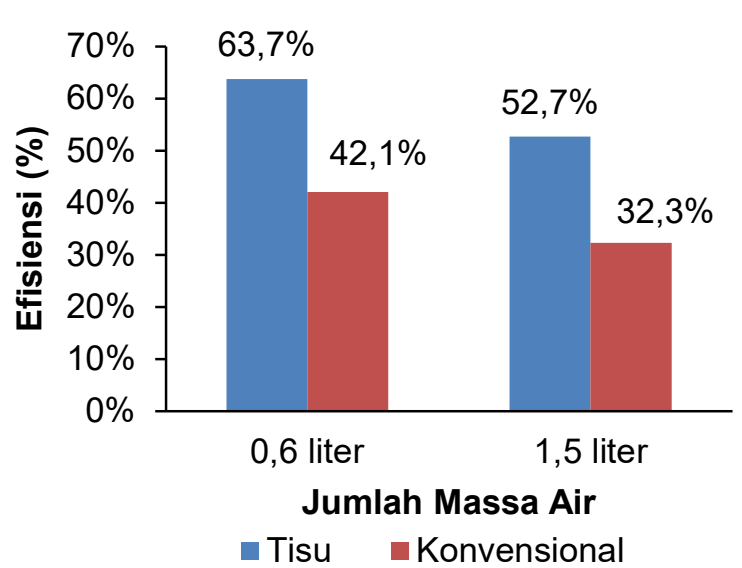

Gambar 13. Efisiensi pada variasi jumlah air dalam bak 0,6 dan 1,5 liter

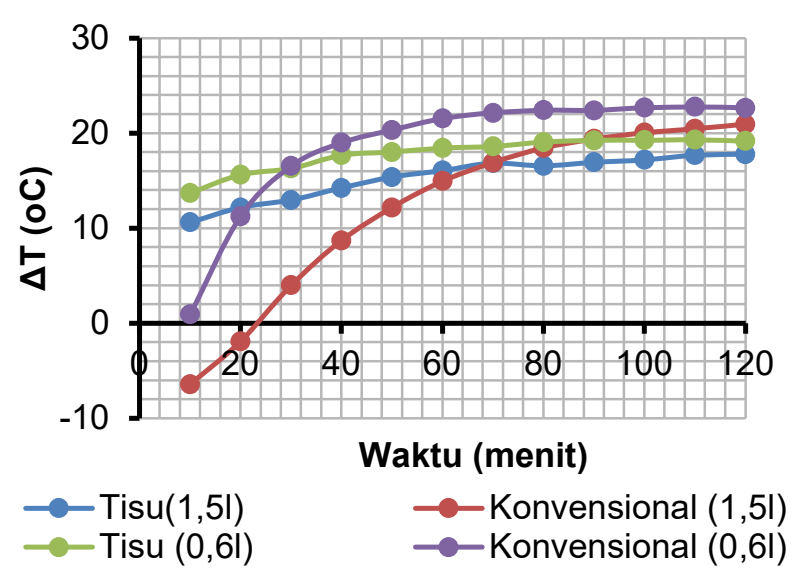

Gambar 14. Perubahan $\Delta \mathrm{T}$ pada variasi jumlah air dalam bak 0,6 dan 1,5 liter

Gambar 13 menunjukan efisiensi distilasi DDP dan konvensional (DTP). Dari grafik terlihat, efisiensi maksimum diperoleh distilasi DDP dengan massa air dalam bak sebesar 0,6 liter yaitu $63,7 \%$ dan $42,1 \%$. Gambar 14 menunjukkan $\Delta T$ pada distilasi DDP dan DTP. Pada saat awal, nilai $\Delta$ T negatif pada distilasi DTP hanya terjadi pada variasi volume air dalam bak sebesar 1,5 liter.

\subsection{Efek Massa Air Yang Terpanasi}

Variasi jumlah massa air yang terpanasi dilakukan dengan mevariasikan jumlah silinder pengapung. Hubungan antara jumlah silinder dengan jumlah massa air diberikan pada Tabel 1. Pada variasi massa air yang terpanasi, jumlah pengapung divariasikan 3, 6 dan 12 silinder. Jenis absorber yang digunakan adalah tisu dan massa air dalam bak sebesar $1,5 \mathrm{~kg}$.

Gambar 15 menunjukkan hasil distilasi terbaik yaitu sebesar $124 \mathrm{ml}$ diperoleh pada variasi pengapung silinder sebanyak 12 . Penggunaan jumlah pengapung 12 silinder membuat massa air yang terpanasi pada satu saat adalah yang paling sedikit. Massa air yang terpanasi pada satu saat dengan 12 silinder adalah 0.36 $\mathrm{kg}$. Massa air yang terpanasi pada satu saat dengan 6 silinder dan 3 silinder adalah $0.93 \mathrm{~kg}$, dan $1.22 \mathrm{~kg}$, sedangkan pada distilasi konvensional (DTP) massa air yang terpanasi pada satu saat adalah $1,5 \mathrm{~kg}$. 


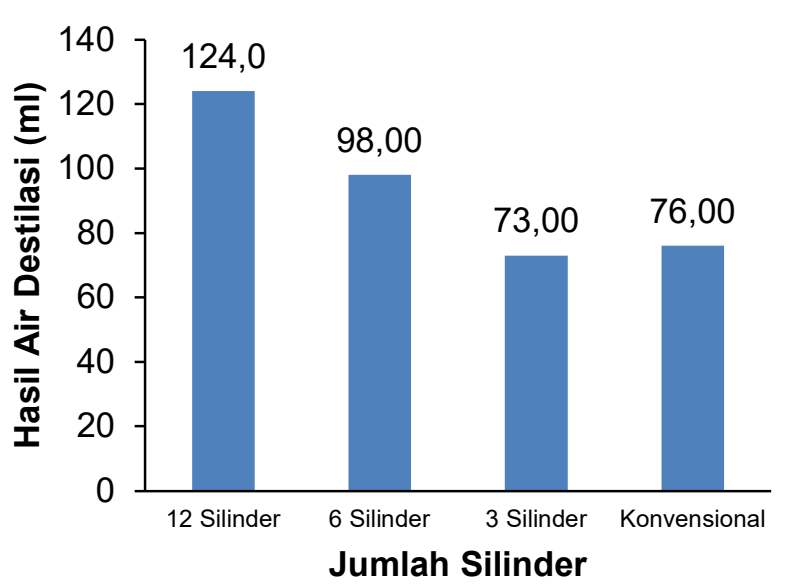

Gambar 15. Hasil air distilasi pada variasi massa air yang terpanasi pada satu saat

Gambar 15 juga menunjukkan penggunaan jumlah pengapung yang terlalu sedikit yakni 3 silinder tidak meningkatkan hasil dan efisiensi. Dari grafik terlihat hasil air distilasi dengan menggunakan 3 silinder dapat dikatakan sama dengan hasil distilasi konvensional (DTP) yakni hanya berbeda $3 \mathrm{ml}$ atau $4,1 \%$.

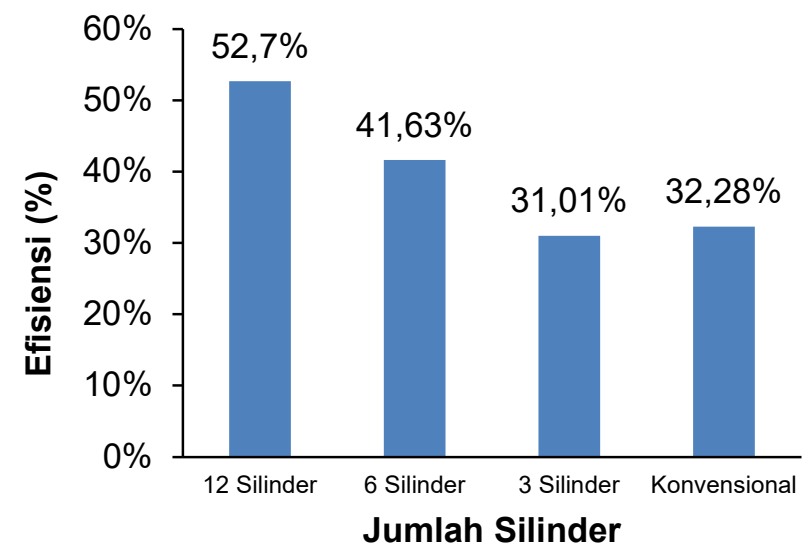

Gambar 16. Efisiensi distilasi pada variasi massa air yang terpanasi pada satu saat

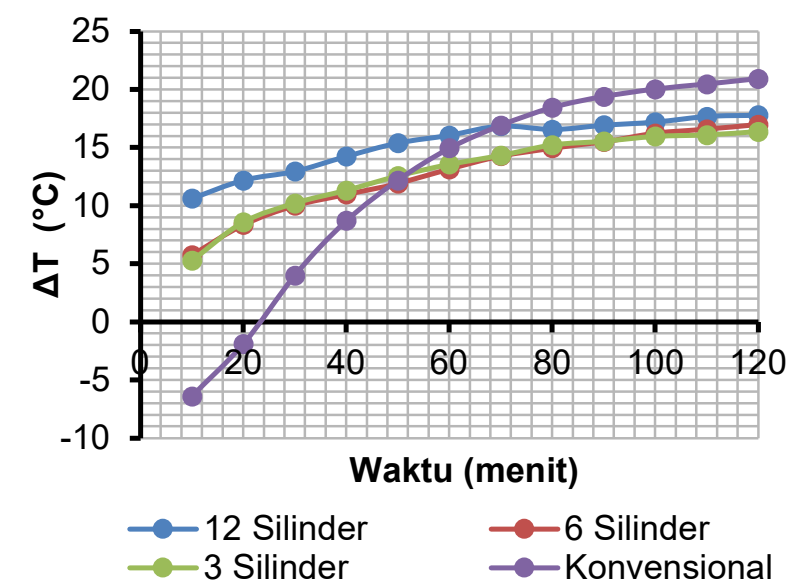

Gambar 17. Perubahan $\Delta \mathrm{T}$ pada variasi massa air yang terpanasi pada satu saat

Gambar 16 menunjukkan efisiensi terbaik terdapat pada jumlah pengapung 12 silinder yaitu 52,57\% sedangkan terendah terjadi pada variasi jumlah pengapung sebanyak 3 silinder yakni 31,01\%.
Gambar 17 merupakan beda temperatur rata-rata tiap 10 menit selama 2 jam. Dari grafik terlihat $\Delta \mathrm{T}$ variasi 12 silinder adalah yang paling besar dari saat awal. Dengan kata lain proses penguapan akan lebih efisien jika massa air yang terpanaskan pada satu saat sedikit. Namun jika jumlah massa air yang terpanaskan pada satu saat terlalu sedikit maka dapat terjadi kekeringan pada absorber. Kondisi kekeringan ini menjadi batasan jumlah massa air minimal yang terpanaskan pada satu saat.

\section{Simpulan}

Penelitian secara eksperimen pada dua model distilasi air jenis bak yakni jenis bak dengan pengapung (DDP) dan tanpa pengapung (DTP) telah dilakukan pada variasi jenis absorber, massa air sekitar, dan massa air yang terpanasi dalam satu saat. Distilasi DTP atau distilasi konvensional digunakan sebagai pembanding unjuk kerja distilasi DDP yang diteliti. Berdasarkan hasil penelitian dapat disimpulkan bahwa:

1. Absorber tisu dengan volume air dalam bak 1,5 liter dan jumlah pengapung 12 silinder menghasilkan air dan efisiensi distilasi tertinggi sebesar $124 \mathrm{ml}$ atau 0,59 liter/(jam. $\mathrm{m}^{2}$ ) dengan efisiensi sebesar $52.7 \%$. Dengan kata lain $63,2 \%$ lebih baik dari distilasi konvensional.

2. Banyak air dalam bak berpengaruh pada hasil air dan efisiensi distilasi jenis bak dengan pengapung silinder. Hasil air dan efisiensi terbaik diperoleh pada variasi air dalam bak sebanyak 0,6 liter yakni $150 \mathrm{ml}$ atau 0,71 liter/(jam. ${ }^{2}$ ) dengan efisiensi $63,7 \%$. Dengan kata lain $51,3 \%$ lebih baik dari distilasi konvensional.

3. Jumlah pengapung menentukan banyak massa air yang terpanasi dalam satu saat. Jumlah pengapung berpengaruh pada hasil air dan efisiensi distilasi jenis bak dengan pengapung silinder. Hasil distilasi terbanyak yaitu $124 \mathrm{ml}$ atau 0,59 liter/ (jam. $\mathrm{m}^{2}$ ) dengan efisiensi sebesar 52,7 $\%$.

Hasil penelitian ini menunjukkan peningkatan hasil dan efisiensi yang baik, selain itu teknologi yang digunakan sangat sederhana. Dengan kata lain hasil penelitian ini sangat mungkin diterapkan.

Penelitian ini juga dapat dikembangkan, misalnya dengan menggunakan bentuk geometri pengapung selain silinder atau menggunakan jenis absorber lain.

\section{Ucapan Terima Kasih}

Penulis berterima kasih atas dukungan keuangan dari LPPM Universitas Sanata Dharma yang diberikan melalui skema Penelitian Umum.

\section{Daftar Pustaka}

[1] P. Dumka, A. Sharma, Y. Kushwah, A. S. Raghav, and D. R. Mishra, "Performance evaluation of single slope solar still augmented with sand-filled cotton bags," J. Energy Storage, vol. 25, no. July, p. 100888, 2019, doi: 10.1016/j.est.2019.100888.

[2] A. E. Kabeel, S. A. El-Agouz, R. Sathyamurthy, and T. Arunkumar, "Augmenting the productivity of solar still using jute cloth knitted with sand heat 
energy storage," Desalination, vol. 443, no. May, pp. 2018, doi: 10.1016/j.desal.2018.05.026.

[3] W. M. Alaian, E. A. Elnegiry, and A. M. Hamed, "Experimental investigation on the performance of solar still augmented with pin-finned wick," Desalination, vol. 379, pp. 10-15, 2016, doi: 10.1016/j.desal.2015.10.010.

[4] K. Kalidasa Murugavel and K. Srithar, "Performance study on basin type double slope solar still with different wick materials and minimum mass of water," Renew. Energy, vol. 36, no. 2, pp. 612-620, 2011, doi: 10.1016/j.renene.2010.08.009.

[5] D. Das, U. Bordoloi, P. Kalita, R. F. Boehm, and A. D. Kamble, "Solar still distillate enhancement techniques and recent developments," Groundw. Sustain. Dev., vol. 10, no. February, p. 100360, 2020, doi: 10.1016/j.gsd.2020.100360.

[6] N. P.K. et al., "Analysis of an inclined solar still with baffles for improving the yield of fresh water," Process Saf. Environ. Prot., vol. 105, pp. 326337, 2017, doi: 10.1016/j.psep.2016.11.018.

[7] H. Sharon, K. S. Reddy, D. Krithika, and L. Philip, "Experimental performance investigation of tilted solar still with basin and wick for distillate quality and enviro-economic aspects," Desalination, vol. 410, pp. 30-54, 2017, doi: 10.1016/j.desal.2017.01.035.

[8] R. S. Hansen, C. S. Narayanan, and K. K. Murugavel, "Performance analysis on inclined solar still with different new wick materials and wire mesh," Desalination, vol. 358, pp. 1-8, 2015, doi: 10.1016/j.desal.2014.12.006.

[9] A. E. Kabeel, Y. Taamneh, R. Sathyamurthy, P. Naveen Kumar, A. M. Manokar, and T. Arunkumar, "Experimental study on conventional solar still integrated with inclined solar still under different water depth," Heat Transf. - Asian Res., vol. 48, no. 1, pp. 100-114, 2019, doi: 10.1002/htj.21370.

[10] R. Samuel Hansen and K. Kalidasa Murugavel, "Enhancement of integrated solar still using different new absorber configurations: An experimental approach," Desalination, vol. 422, no. April, pp. 59-67, 2017, doi: 10.1016/j.desal.2017.08.015.

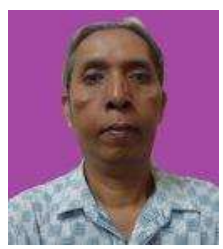

FA. Rusdi Sambada menyelesaikan pendidikan S1 Teknik Mesin di Universitas Gadjah Mada pada tahun 1993. Pendidikan magister Teknik Mesin diselesaikan di Universitas Gadjah Mada pada tahun 1998 dengan area riset tentang energi surya.

Saat ini ia bekerja sebagai dosen di Jurusan Teknik Mesin Uinversitas Sanata Dharma Yogyakarta. Bidang penelitian utama yang digeluti adalah solar energy, heat transfer dan TrnSys. 